This is an Open Access article distributed under the terms of the Creative Commons Attribution 4.0 International License which permits unrestricted non-commercial use, distribution, and reproduction in any medium, provided the original work is properly cited

\title{
THE EFFECTIVENESS OF ORAL CRYOTHERAPY TO REDUCE ORAL MUCOSITIS AMONG CANCER PATIENTS UNDERGOING CHEMOTHERAPY: A LITERATURE REVIEW
}

\author{
Elteria Sianturi ${ }^{1}$, Dewi Irawati ${ }^{2}$
}

\author{
1 Magister Student of Faculty of Nursing, University of Indonesia, Depok, Indonesia \\ 2 Department of Medical Surgical Nursing, Faculty of Nursing, University of \\ Indonesia, Depok, Indonesia \\ * Correspondence: elteria19@gmail.com
}

\begin{abstract}
Oral cryotherapy has been scientifically proven as a non-pharmacological therapy to reduce the incidence of oral mucositis. With the decline in the incidence of oral mucositis, patient's comfort improved, the length of stay and cost of care decreases, and maximum quality of life is achieved. To determine the effectiveness of oral cryotherapy in reducing the incidence of oral mucositis in patient undergoing chemotherapy. This paper used literature review. The literature search was conducted of articles published from January 2012 through February 2018 using the PubMed, Embase, Cochrane Library and Ebscohost databases on the effectiveness of oral cryotherapy in reducing oral mucositis in patients undergoing chemotherapy. This search resulted in a total of 8 articles. Evidence has indicated that there is a significance effect of oral cryotherapy in reducing oral mucositis. Oral cryotherapy is one of technique that easy to do, inexpensive and can be tolerated by patients in general, so it can be used widely. It can be used for adults and children with solid tumors, bone marrow transplant patients and for patients with different chemotherapy regimens (single or combination regimens).
\end{abstract}

Keywords: Oral Cryotherapy, Oral mucositis, chemotherapy, quality of life

\section{Introduction}

Cancer is one of the leading causes of death worldwide. Cancer is a group of diseases characterized by the growth of abnormal cells beyond their usual boundaries that can invade adjoining parts of the body and or spread to other organ. Cancer is the second leading cause of death globally and is estimated to account for 9.6 million deaths in 2018 (1). The increase of cancer cases is caused by several factors, including population growth, aging process, and a change in the prevalence of certain cancer causes associated with socio-economic development. More than $30 \%$ of death is caused by five behavioral and dietary factors, namely high body mass index, lack of fruit and vegetable intake, lack of physical activity, cigarette, and excessive alcohol consumption. Smoking is a major factor of 
cancer which causes more than $20 \%$ deaths in the world and about $70 \%$ of lung cancer deaths world wide (2).

Nasopharyngeal Cancer (NPC) is the most common Head and Neck cancer and is ranked fourth in neck and head cancer which is most commonly found in men. The prevalence of NPC in Indonesia based on histopathology is reported to be around 6.2 cases for every 100,000 population each year (3). NPC is a type of squamous epithelial cancer originating from the surface of the lateral nasopharynx wall. The cause of NPC is strongly associated with Epstein-Barr virus (EBV) (4).

There are several types of treatment for cancer (5). Usually the patients will only undergo one therapy, but some patients generally undergo combination therapy such as surgery with chemotherapy and or with radiation therapy. Determination of therapy depends on the stage of cancer. Chemotherapy is an important component for cancer therapy. It affects all cells that grow and cleave rapidly in the body which include new blood cells in the bone marrow, cells in the mouth, stomach, skin, hair and reproductive organs. When it destroys normal cells, it would cause side effects $(6,7)$.

The side effects of chemotherapy could affect physical health, quality of life and emotional status of the patients (8). Cancer therapy such as chemotherapy, radiotherapy or therapeutic targets in Head and Neck cancer could cause oral toxic side effect (9). One of side effects mostly studied is oral mucositis. It is experienced by about $40 \%$ patients whom are treated with standard-dose chemotherapy, and up to $80 \%$ patients from them receive high-dose chemotherapy (10) The side effect which is common and must be treated in radio therapy and chemotherapy is oral mucositis because it could worsen the quality of life of patients with NPC (11).

Oral mucositis can be experienced by children and adults and can affect patients physically and psychologically. Inflammation and ulceration cause the patients difficult to eat, swallow, talk or do oral hygiene steps (12). Oral mucositis can also cause weight loss and dehydration (13). The severity of oral mucositis is very diverse. The most severe conditions are characterized by extensive ulceration causing inability to swallow food, poor quality of life and treatment discontinuation (14). It also depends on several factors which are related to diagnosis and treatment such as treatment duration after previous chemotherapy, daily dose of radiation, chemotherapy with radiation, patient's characteristics, oral hygiene and other factors (15) V Various local and systemic methods are used to manage oral mucositis, but there is no method or combination methods yet that show effective, comprehensive and free from secondary effects (16).

As it is important to prevent oral mucositis severity, it is necessary to conduct research on the most appropriate interventions including complementary therapies and alternatives for the oral mucositis management.Some evidence-based literature says that oral cryotherapy can reduce the growth of oral mucositis for patients undergoing chemotherapy.

\section{Method}

\section{Data sources}

A Literatur review was applied in this study. Several data bases used to obtain relevant articles including Pubmed, Cochrane Library, EbscoHost and Google Scholar. 


\section{Search strategy}

The search keywords including "oral mucositis", "oral cryotherapy", "Cancer", and "Chemotherapy". These terminologies are used in combination so that the literature found is more specific.

\section{Inclusion criteria}

The article search inclusion criteria is (1) a discussion article about oral mucositis and the efficacy of oral cryotherapy in patient that undergo chemotherapy; and (2) Englishlanguage articles. In addition, searches are limited to articles containing full text from January 2012 to February 2018.

\section{Results}

The search results about 10 articles that related to inclusion critera, but only 7 articles used because these articles already represent this study, besides contain different kind of chemotherapy agen also different kind of cancer. The articles consisting of 1 retrospective cohort study article, 1 article quasi experiment study, 5 randomized controlled trial articles (table 1).

\section{a. Definition of oral mucositis}

Mucositis is the inflammation and ulceration of the superficial membrane overlying the digestive tract from the mouth to the anus. When the inflammation of the mucous involves the mouth and oral oropharyngeal segment, it is called oral mucositis (17)· Oral mucositis is one of the most recurrent and potentially severe complications of chemotherapy which has a significant impact on patient's quality of life (18).

\section{b. Definition of oral cryotherapy}

Oral cryotherapy is the application of ice chips or ice-cold water to the mouth. Oral cryotherapy for chemotherapy-induced OM requires that patients suck on ice chips before, during, and after infusions of mucotoxic drugs (19). The theory underlying oral cryotherapy is that ice can constrict the blood vessels of the oral cavity membranes, therefore decreasing exposure of the oral mucosa to mucotoxic agents (20).

\section{c. Instrument of Oral Mucositis}

1) WHO mucositis scale

The simplest established grading systems that incorporates both subjective and objective criteria, and the validity of the scale has been established in several studies. To determine the severity of the oral mucositis, it was divided into 5 specific degrees of $0-4$ (19). The WHO mucositis has 5 grading scale: grade 0 : normal, grade 1: erythema/mild/soreness, grade 2: painful erythema/edema/ ulcers/able to eat, grade 3: painful erythema/edema/ulcers/ not able to eat, and grade 4: requires parenteral/enteral support) (22).

2) Oral assessment guide (OAG)

Used to evaluate the condition of oral cavity and the degree of stomatitis for children. The tool assesses eight items: swallow lips and corner of the mouth, tongue, saliva, mucus membrane, voice, gingivae and teeth. Oral assessment guide has a three point scale that is used for answer or responses as the following: score one indicates to normal findings Score two for mild abnormality without compromise of either mucosal integrity or loss of function and score three for severe abnormality with 
compromise of either mucosal integrity or loss of function. The total scores equal 24 marks covered 8 items and was categorized as the following: 1 to 8: indicates healthy oral cavity, 9 to 16: indicates moderate stomatitis, 17 to 24: indicates sever stomatitis (13).

\section{d. Effect of oral cryotherapy to reduce oral mucositis}

In one study, it was explained that oral cryotherapy has a significant contribution to the protection of oral health by reducing mucositis. The result of the present study reveals that there was highly significant decrease in the occurrence of oral mucositis observed in the children treated with flavored (honey and tulsi) ice cubes than plain ice cubes at $p<0.001$ on 5 th day as well as on 15th day following chemo therapy. Present study supports to the similar study where they have reported the similar findings that there was significant reduction in incidence of oral mucositis among the children receiving flavored ice cubes than plain ice cubes on 5 th day and $15^{\text {th }}$ day at $p=0.001$ (18). Another study for 60 children having bone tumor for the first time and receiving primary line of chemotherapy concluded thar children who received oral ice cubes had healthier oral cavity than who did not receive. Indicated that the mean total oral assessment scores was a statistically significant different between the study and control group at 3rd, 4th and 5th days post cryotherapy at a significance level as $\mathrm{p}<0.001$ (13).

The other study in out patient for total 30 cancer patients that consisted chemotherapy regimen of only bolus intravenous 5-fluorouracil and leucovorin explained that in the majority of patients receiving cryotherapy, oral mucositis was not observed (Grade 0 ) at 7 and 14 days. Similarly, incidence of Grades 1, 2, and 3 oral mucositis in the experimental group was quite a bit lower when compared to the control group ( $p<0.05$ ). On day 21 , no statistically significant difference between the experimental and control groups was determined based on the development of oral mucositis ( $p>0.05)$ (21). This study is according to study for 80 patients with colorectal cancer that received fluorouracil-based chemotherapy at their first cycle of chemotherapy in out patients explained a statistically significant difference was found between the mean mucositis scores in the intervention (oral cryotherapy) and usual care groups ( $p<0.05)(10)$.

Another Randomized Controlled Trial (RCT) studies for 80 breast and colorectal cancer patients that received combination chemotherapy in out patient explained that the incidence of oral mucositis in the intervention group with oral cryotherapy that receive chemotherapy (45\%) was significantly lower than the control group $(77.5 \% ; \mathrm{P}=0.01)$ (20). In addition study for 29 patients undergoing stem cell transplantation concluded that oral cryotherapy is more effective than the saline mouthwash in reducing the severity of mucositis. The severity of the mucositis in the cryotherapy group was significantly less than that in the saline mouthwash group $(1.81<2.54$ and $0.13<0.92$, respectively) on the 7 th and 14 th days $(\mathrm{P}<0.05)$. This method is recommended for the prevention of mucositis in bone marrow transplantation (19). One retrospective cohort study analyzes the impact of oral cryotherapy (OC) or room temperature saline rinses on the prevention of Oral Mucositis for 134 cancer patients with multiple myeloma (MM) or lymphoid neoplasias submitted to autologous stem cell transplantation (ASCT) in a single center explained that Oral mucositis developed in 85/134 cases (63\%), being the incidence significantly lower in the OC group [29 (44\%) vs. 56 (82\%), P < 0.001 (22). 
Table 1. Description of studies included in the literature review

\begin{tabular}{|c|c|c|c|c|}
\hline Reference & Study design & Aim of study & $\begin{array}{c}\text { Method/instrument } \\
\text { used }\end{array}$ & Result \\
\hline$[21]$ & $\begin{array}{c}\text { randomized } \\
\text { controlled trial }\end{array}$ & $\begin{array}{l}\text { To assess the effect of oral } \\
\text { cryotherapy on the development of } \\
\text { oral mucositis related to infusion } \\
\text { of } 5 \text {-fluorouracil (5-FU) with } \\
\text { leucovorin. }\end{array}$ & WHO mucositis scale & $\begin{array}{l}\text { oral cryotherapy has a } \\
\text { significant contribution to } \\
\text { the protection of oral } \\
\text { health by reducing } \\
\text { mucositis score especially } \\
\text { on the } 7 \text { th and 14th days. }\end{array}$ \\
\hline$[20]$ & $\begin{array}{c}\text { randomized } \\
\text { controlled trial }\end{array}$ & $\begin{array}{l}\text { To assesses the effect of oral } \\
\text { cryotherapy on the incidence and } \\
\text { severity of chemotherapy-induced } \\
\text { oral mucositis in combined } \\
\text { chemotherapy regimens. }\end{array}$ & WHO mucositis scale & $\begin{array}{l}\text { Oral cryotherapy because } \\
\text { of its ease of application, } \\
\text { tolerability and lack of side } \\
\text { effects makes it an } \\
\text { important resource for } \\
\text { reducing the incidence and } \\
\text { severity of oral mucositis. }\end{array}$ \\
\hline$[13]$ & $\begin{array}{l}\text { A quasi- } \\
\text { experimental } \\
\text { design }\end{array}$ & $\begin{array}{l}\text { To evaluate the effect of oral } \\
\text { cryotherapy on the occurrence of } \\
\text { stomatitis induced by } \\
\text { chemotherapy among children } \\
\text { with bone tumors. }\end{array}$ & $\begin{array}{l}\text { Oral assessment guide } \\
\qquad \text { (OAG) }\end{array}$ & $\begin{array}{l}\text { Children who received oral } \\
\text { ice cubes had healthier oral } \\
\text { cavity than who did not } \\
\text { receive. It was concluded } \\
\text { that oral cryotherapy } \\
\text { reduces the severity of } \\
\text { stomatitis induced by } \\
\text { chemotherapy. }\end{array}$ \\
\hline$[22]$ & $\begin{array}{l}\text { retrospective } \\
\text { cohort study }\end{array}$ & $\begin{array}{l}\text { To analyzes the impact of oral } \\
\text { cryotherapy or room temperature } \\
\text { saline rinses on the prevention of } \\
\text { oral mucositis in patients with } \\
\text { multiple myeloma (MM) or } \\
\text { lymphoid neoplasias submitted to } \\
\text { autologous stem cell } \\
\text { transplantation (ASCT) in a single } \\
\text { center }\end{array}$ & WHO mucositis scale & $\begin{array}{l}\text { Oral cryotherapy is more } \\
\text { effective than saline rinses } \\
\text { in the prevention of oral } \\
\text { mucositis in patients with } \\
\text { lymphoma and myeloma } \\
\text { receiving conditioning } \\
\text { regimens with high-dose } \\
\text { melphalan for ASCT. }\end{array}$ \\
\hline [19] & $\begin{array}{c}\text { randomized } \\
\text { controlled trial }\end{array}$ & $\begin{array}{l}\text { To investigate the effects of } \\
\text { local cryotherapy on the } \\
\text { intensity of chemotherapy- } \\
\text { induced oral mucositis in } \\
\text { autologous bone marrow } \\
\text { transplantation patients. }\end{array}$ & WHO mucositis scale & $\begin{array}{l}\text { Cryotherapy is more } \\
\text { effective than the saline } \\
\text { mouthwash in reducing } \\
\text { the severity of } \\
\text { mucositis. This method } \\
\text { is recommended for the } \\
\text { prevention of mucositis } \\
\text { in bone marrow } \\
\text { transplantation. }\end{array}$ \\
\hline [18] & $\begin{array}{c}\text { randomized } \\
\text { controlled trial }\end{array}$ & $\begin{array}{l}\text { To investigate the effect of } \\
\text { flavored (honey and tulsi) ice } \\
\text { chips Vs plain ice chipson oral } \\
\text { mucositis following chemotherapy }\end{array}$ & WHO mucositis scale & $\begin{array}{l}\text { The flavored ice cubes } \\
\text { (honey and tulsi) is more } \\
\text { effective than plain ice } \\
\text { cubes in reduction of oral } \\
\text { mucositis in the patient } \\
\text { receiving methotraxate. }\end{array}$ \\
\hline$[10]$ & $\begin{array}{c}\text { randomized } \\
\text { controlled trial }\end{array}$ & $\begin{array}{l}\text { To evaluate the effect of oral } \\
\text { cryotherapy on the prevention of } \\
\text { oral mucositis and pain among } \\
\text { patients with colorectal cancer } \\
\text { undergoing fluorouracil-based } \\
\text { chemotherapy. }\end{array}$ & WHO mucositis scale & $\begin{array}{l}\text { The potential benefit of } \\
\text { cryotherapy in the } \\
\text { prevention of oral } \\
\text { mucositis and associated } \\
\text { pain appears to improve } \\
\text { the quality of life of } \\
\text { patients undergoing } \\
\text { fluorouracil-based } \\
\text { chemotherapy. }\end{array}$ \\
\hline
\end{tabular}




\section{Discussion}

Oral mucositis is one of the most recurrent and potentially severe complications of chemotherapy which has a significant impact on patient's quality of life (18). There are two instruments used to asses the oral mucositis including WHO mucositis scale and Oral assessment guide (OAG). Each of these instrument has its own in scoring oral mucositis.

Cancer is the second leading cause of death globally and is estimated to account for 9.6 million deaths in 2018 (1). In Indonesia cancer prevalence increased from 1.4 percent in 2013 to 1.8 percent in 2018 (23). It can be estimated that people who suffer with cancer will increase.

Oral cryotherapy is the application of ice chips or ice-cold water to the mouth during the administration of chemotherapy and is used to prevent and manage oral mucositis and associated pain. Oral ice chips induce vasoconstriction to the blood vessels in the oral cavity by limiting the exposure to cytotoxic drug effects. This regional hypothermia may prevent and reduce the amount of drug reaching the oral mucous membranes, limiting mucositis caused by the local cytotoxic activity of antineoplastic drugs (24). Oral Cryotherapy has significant contribution to the protection of oral health by reducing mucositis score for cancer patients undergoing chemotherapy (21). Oral cryotherapy can be applied in Indonesia to reduce the severity of oral mucositis especially for cancer patient that receive chemotherapy. From the discussion of some of the articles above, oral cryotherapy is simple and inexpensive method of treating oral mucositis. This method is recommended for the prevention of mucositis in patient with solid tumor, bone marrow transplantation, applicable for adult and children.

\section{Conclusion}

Oral cryotherapy is one of the non-pharmacological actions useful for reducing the incidence and severity of oral mucositis in cancer patients undergoing chemotherapy. This technique is easy to do, inexpensive and can be tolerated by patients in general, so it can be used widely. It can be used for adults and children with solid tumors, bone marrow transplant patients and for patients with different chemotherapy regimens (single or combination regimens).

Many studies discuss the role of oral cryotherapy in reducing the incidence of mucositis in the hope to increase patients' comfort, decrease length of stay, increase adherence to chemotherapy so that the patients' quality of life are expected to increase. As high incidence in oral mucositis, the application of oral cryotherapy needs to be done in the oncology care. Nurses play role in educating and facilitating the implementation of oral cryotherapy in patients undergoing chemotherapy. Nurses also play a role in enhancing ongoing research related to oral mucositis incidence in order to improve nursing care in order to provide comfort and ultimately improve the quality of life of the patients. .

\section{Study Limitations}

The limitations of this paper is the type of method used is the literature review so that the writing method used is not systematic, but the strength of this paper is already discuss all the effect of oral cryotherapy to reduce oral mucositis for patient undergoing chemotherapy. Moreover it also conclude that oral cryotherapy is a method that worth it to be applied in order to improve nursing care. 


\section{Reference}

1. World Health Organization. Cancer.2018. http://www.who.int/cancer/en/.

2. Infodatin Kementerian Kesehatan Republik Indonesia.(2015). Situasi penyakit kanker di Indonesia.http://www.depkes.go.id/resources/download/pusdatin/infodatin/info datin-kanker.pdf.

3. Adham M, Kurniawan AN, Muhtadi AI, Roezin A, Hermani B, Gondhowiardjo S. Nasopharyngeal carcinoma in Indonesia: epidemiology, incidence, signs, and symptoms atpresentation. Chin J Cancer. 2012; 31(4):185-196.

4. Gulley ML.Molecular diagnosis of Epstein-Barr virus related diseases. the journal of molecular diagnosis.2010.

5. National Cancer Institute. 2018. Cancer prevalence. Bethesda, MD.

6. American Cancer Society. After diagnosis: A guide for patients and families. 2012. http://www.cancer.org/acs/groups/cid/documents/webcontent/002813-pdf.pdf.

7. Cancer Council. (2018). Managing chemotherapy side effects.https: www. Cancer council.com.au/ cancer information/ cancer treatment/ chemotherapy /side-effects

8. Carelle N, Piotto E, Bellanger, Germanaud J, Thuillier A., Khayat D. Changing patient perceptions of the side effects of cancer chemotherapy. Cancer.2002; 95 (1): p.155163.

9. Al-Dasooqi N, Sonis ST, Bowen JM, Bateman E, Blijlevens N, Gibson RJ. Emerging evidence on the pathobiology of mucositis. Supportive Care in Cancer.2013;21(11): 3233-41.

10. Nawi RIL, Chui PL,Ishak WZW, Chan CMH. Oral Cryotherapy: Prevention of oral mucositis and pain among patients with colorectal cancer undergoing chemotherapy. Clinical Journal Of Oncology Nursing.2018;22(5).

11. Qutoba AB, Gueb S, Revesz T, Logan RM, Keefe D. Prevention of oral mucositis in children receiving cancer therapy: a systematic review and evidence-based analysis. Oral Oncology.2013; 49, 102-107.

12. Barkokebas A, Silva IH, de Andrade SC. Impact of oral mucositis on oral-healthrelated quality of life of patients diagnosed with cancer. J Oral PatholMed.2015;44:746-751.

13. Rashad H M. Effect of Cryotherapy on the Occurrence of Stomatitis Induced by Chemotherapy among Children with Bone Tumors in Egypt. Journal of Biology, Agriculture and Healthcare. 2014; 4(18), 49-58.

14. Mercadante S, Aielli F, Adile C. Prevalence of oral mucositis, dry mouth, and dysphagia in advanced cancer patients. Support. Care Cancer.2015; 23, 3249-3255.

15. Mallick S, Benson R, Rath GK. Radiation induced oral mucositis: a review of current literature on prevention and management. Eur. Arch. Oto-Rhino-Laryngol. 2016; 273, 2285-2293.

16. Lalla R V, Sonis S T, Peterson D E. Management of Oral Mucositis in Patients Who Have Cancer. Dental Clinics of North America.2008; 52(1), 61-77.

17. Sonis ST. The pathobiology of mucositis. Nat Rev Cancer. 2004;4(4):277-84. doi: 10.1038/nrc1318. [PubMed: 15057287].

18. Nayak, G. Effect of flavoured ice chips in reduction of oral mucositis among children receiving chemotherapy.Int. J. Pharm. 2017;43(1),07,25-28.

19. Askarifar M, Lakdizaji S, Ramzi M, Rahmani A, Jabbarzadeh F. The Effects of Oral Cryotherapy on Chemotherapy-Induced Oral Mucositis in Patients Undergoing 
Autologous Transplantation of Blood Stem Cells: A Clinical Trial. Iranian Red Crescent Medical Journal, In press(In press). 2016;18(4):e24775

20. Heydari A, Sharifi H, Salek R. Effect of Oral Cryotherapy on Combination Chemotherapy-induced Oral Mucositis : A Randomized Clinical Trial.2012; 3, 55-64.

21. Katranci N, Ovayolu N, Ovayolu O, Sevinc A. European Journal of Oncology Nursing Evaluation of the effect of cryotherapy in preventing oral mucositis associated with chemotherapy e A randomized controlled trial. 2012; 16, 339-344.

22. Batlle M, Morgades M, Vives S, Ferra C, Oriol A, Sancho JM, Ribera JM. Usefulness and safety of oral cryotherapy in the prevention of oral mucositis after conditioning regimens with high-dose melphalan for autologous stem cell transplantation for lymphoma and myeloma. European Journal of Haematology.2014; 93(6), 487-491.

23. Riset Kesehatan Dasar Kementerian Kesehatan.2018. www.depkes.go.id/hasilriskesdas-2018.

24. Peterson DE, Bensadoun RJ, Roila F, Group EGW. Management of oral and gastrointestinal mucositis: ESMO clinical practice guidelines. Ann Oncol 22 Suppl.2011; 6:vi78-84. 